\title{
ВЕРБАЛІЗАЦІЯ КОНЦЕПТУ ,БОГ У БАЙКАХ СВІТОВИХ СТЕПАНА РУДАНСЬКОГО
}

\author{
НАТАЛІЯ ПІДДУБНА \\ Харківський національний педагогічний університет імені Г. С. Сковороди, \\ Харків - Україна \\ WERBALIZACJA KONCEPTU „BÓG” \\ W BAJKACH SWITOWYCH STEPANA RUDANSKIEGO \\ NATALIA PIDDUBNA \\ Charkowski Narodowy Uniwersytet Pedagogiczny im. Hryhorija Skoworody, \\ Charków - Ukraina
}

STRESZCZENIE. Artykuł został poświęcony analizie specyfiki werbalizacji konceptu „Bóg” w poemacie Stepana Rudanskiego „Bajky switowi”. Wskazano środki językowe charakteryzujące Boga w utworze, które odzwierciedlają wyjątkową pozycję Boga w kulturze narodu.

\section{VERBALIZATION OF THE CONCEPT „GOD” IN BAJKY SVITOVI BY STEPAN RUDANSKY}

\section{NATALIA PIDDUBNA \\ H. S. Skovoroda Kharkiv National Pedagogical University, Kharkiv — Ukraine}

ABSTRACT. The article is devoted to the analysis of the specificity of verbalization of the concept "God" in the poem "Bajky Svitovi" by Stepan Rudanskiy. The means of language characteristics of God have been found out. The general language tendencies to show respect to God according to the traditions of the Ukrainian lingual and humorous culture have also been defined.

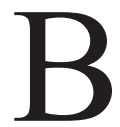

історії української літературної мови є чимало особистостей, які зробили значний внесок у іiї утвердження й розвій, але не були належно поціновані ні сучасниками, ні нащадками. Однією з таких постатей є С. Руданський, якого незаслужено зачислили до письменників другого ряду. Однак Степан Руданський - поет, перекладач, лікар - самовіддано був закоханий в українське слово, яке плекав і в холодному Петрополі (так він називав Санкт-Петербург), де молодий українець, учорашній випускник Кам'янець-Подільської духовної семінарії, усупереч волі зросійщеного батька-священика здобував вищу освіту в медико-хірургічній академії, і в спекотній Ялті, де йому довелося працювати лікарем. Однак за життя письменника світ побачила лише незначна частина його творів, причиною чому стала царська цензура, заборона українського слова, а також нестача коштів для видання співомовок.

Повне зібрання всіх творів С. Руданського в одному томі, куди ввійшли раніше не публіковані історичні поеми Мазепа, гетьман украӥнський та Іван Скоропада, патріотична поезія До України („Ой з-за гори, із-за кручі”), а також 63 приказки-співомовки, з'явилося лише 2007 року. 
Студії над творчістю С. Руданського, розпочаті І. Франком, у першій половині ХХ ст. продовжили А. Кримський, С. Сфремов, В. Лукич, І. Брик, В. Герасименко, М. Левченко. Із 60-х років XX ст. і до сьогодні поетична спадщина С. Руданського потрапляє у фокус наукових студій М. Білокопитова, Г. Зленка, I. Пільгука, І. Приходько, М. Сиваченка, Г. Нудьги, С. Кисельова, П. Колесника, Ю. Цекова, В. Кравченка, К. Пирогової та ін.

Однак творчий доробок письменника часто аналізували необ'єктивно, спрощено, з опертям на радянську антирелігійну й антинаціональну ідеологію. Повертаючи широкому читачеві не публіковані раніше твори письменника, Г. Латник, укладач останнього найповнішого видання С. Руданського, наголошує, що їхнє несправедливе замовчування значною мірою було спричинене комплексом національної меншовартості, упродовж тривалого часу прищеплюваного українцям: „Я вважаю гуморески-співомовки Степана Руданського гідними порівняння $з$ книжкою великого французького письменника-гуманіста доби середньовіччя Франсуа Рабле Гаргантюа i Пантагрюель. А ще гадаю, що царська та більшовицька цензура і меншовартісномалоросійський переляк просто вкрали у кількох поколінь українського народу великий сміх поета-самородка Степана Руданського. Пишаюся тим, що доля присудила мені повернути неоціненний творчий скарб українському народові”".

У науковій літературі натрапляємо на скупі характеристики творчості С. Руданського, якого хоч і називають автором нового жанру співомовок, однак спрощують розуміння цього терміна до власне гуморесок або віршованих анекдотів ${ }^{2}$, суттєво елімінізуючи творчий набуток поета, залишаючи ніби осторонь його ліричні твори. Значною мірою таке звуження було ідеологічно вмотивованим, адже за часів радянської влади значна частина творів поета ретельно „фільтрувалася”; у його ліричних творах і поемах піднімалися гострі соціальні питання: С. Руданський виявив себе як письменник, у якого „національна ідея знайшла вияв у формі експресивного оскарження неволі України, хто зробив яскраві акценти на державницьких прагненнях діячів минулого в українській історії, хто різними способами, у різних жанрових формах виступив на захист українського слова, культури, прав своєї зневаженої нації, < .. > хто писав "Байки світовії” з метою нагадати ще й ще раз про те, як нищать українця в українцеві чужою школою, чужою, накинутою йому мовою"з. Тому під час вивчення творчості С. Руданського акценти робили на соціально нейтральних співомовках-анекдотах, i саме вони позиціонувалися як основний творчий набуток письменника.

Поза увагою сучасних дослідників залишається й лінгвістичний аспект дослідження творчості С. Руданського, адже на сьогодні українське мовознавство налічує лише кілька робіт, присвячених вивченню мови поета. Це, зокрема, грунтовна стаття С. Срмоленко ${ }^{4}$, стаття-діалог С. Срмоленко і С. Попель ${ }^{5}$, наукова розвідка Н. Піддубної6 та деякі ін.

\footnotetext{
${ }^{1}$ Г. Латник, Украйнський Рабле, [в:] Степан Руданський, Київ 2007, с. 7.

${ }^{2}$ В. М. Русанів ський, Історія української літературної мови, Київ 2002, с. 237.

${ }^{3}$ I. Приходько, Украӥнська література XIX-nоч. ХХ ст. у новому осмисленні: Для тих, хто хоче знати більше, Львів 2006, с. 8.

4 С. Єрмоленко, Мовно-естетичні знаки української культури у творах Степана Руданського, [в:] У вимірах слова, Зб. наук. праць (до ювілею проф. кафедри української мови Л. Г. Савченко, Харків 2009, с. 15-21.

5 С. Срмоленко, С. Попель, У вінок Степанові Руданському, [в:] Електронний pecypc:www.ualogos.kiev.ua/fulltext.html?id=1613. (доступ 02.02.2013 p.).

${ }^{6}$ Н. В. Піддубна, Мовний образ священнослужителя в співомовках Степана Руданського, [в:] “Лінгвістичні дослідження”, Зб. наук. праць Харків. нац. пед ун-ту ім. Г. С. Сковороди, за ред. проф. Л. А. Лисиченко, Харків 2014, вип. 38, с.160-168.
} 
Авторка цієї наукової студії має на меті з'ясувати особливості вербалізації концепту „Бог” як одного із центральних в українській МКС у надзвичайно вагомому для творчості поета ліричному творі - Байках світових (Лірникових думах).

Поет доклав багато зусиль для збагачення національного фонду української літератури, зокрема через власну інтерпретацію світових біблійних сюжетів, відображених у великому епічному творі Байки світовї, що складаються $з$ п'яти дум: Початок світу, Велетні, Цар Давид, Премудрий Соломон і Бог на землі. Поет прагнув осмислити народне світобачення, морально-етичні уявлення українців про світ на основі християнської моралі, об'єднавши народні оповідки в єдине ціле. Він писав, що одне зі своїх завдань убачає в тому, щоб „відшукати нитку межи тими різними уривками, котрі мені то сям, то там удалось позбирати, i, наскілько можна, споїти в їдну співу"7. Письменник мріяв про те, щоб його твір набув музичного супроводу на кобзі чи лірі й саме так поширювався серед українців. У „Преслівлі” до запису людських оповідок, що їх С. Руданський об’єднав у цілісний твір, він зазначає: „А все-таки надіюсь, що хто-небудь... захоче дати голос на мої Світовї сnіви, — ото я для них і прикладаю ці людські оповідки"я.

Обробка й фіксація апокрифічних легенд про початок створення світу, людей, тварин тощо, безперечно, була важливою для письменника саме українською мовою, у чому виявляється й новаторство С. Руданського, і його патріотична громадянська позиція.

Автор Байок світових надає апокрифічним оповіданням особливої тональності, інтимізуючи біблійні легенди. Колоритним є й образ оповідача, „який знаходить ліричні, жартівливі вислови для переказування „високих” тем, для індивідуалізації усталених народнопоетичних образів”, порівн.: „Наступає тиха нічка, / Світять ясні зорі, / I в тумани, як в намітку, / Завинулись гори. / На полудні, де Карпата / Кинула відлоги, / Вколо Смотричем повився / Кам'янеиь убогий"'10.

Однак у часи радянського войовничого атеїзму ця поема характеризувалася винятково як „антицерковна епопея, написана блискучим віршем”"11, оскільки „подавала канонічні біблійні легенди в перекрученому, а подеколи і в комічному варіанті” 12 , як така, що проникнута „одвертими богоборчими мотивами”, „розважливо-поблажливим ставленням до сонму небожителів, яких наділено звичайнісінькими людськими слабостями й вадами"13. У передмові до тритомового видання творів С. Руданського П. Колесник зазначав: „Це не що інше, як народна біблія, одверто протиставлена біблії канонічній. Побудовано iii на єретичних оповідках, записаних автором з уст народу. Зміст оповідок такий, що ніяка цензура не дозволила б їх друкувати, не кажучи вже про цензуру духовну"14.

\footnotetext{
${ }^{7}$ С. Руданський, Твори, у 3 томах, Київ 1973, т. 2, с. 37.

${ }^{8}$ Там само, с. 337.

${ }^{9}$ С. Срмоленко, Зазнач. джерело, с. 21.

${ }^{10}$ С. Руданський, Співомовки. Переклади та переспіви, Київ1985, с. 203 - далі подаємо
} поклики на це видання в круглих дужках, зазначаючи конкретну сторінку.

${ }^{11}$ П. Й. Колесник, Степан Руданський. Літературний портрет, Київ 1971, с. 87.

${ }_{12}$ Ю. І. Цеков, Степан Руданський. Нарис життя і творчості, Київ 1983, с. 116.

${ }_{13}^{13}$ П. Гопчен ко, Полум'яний атеїст, [в:] Степанові Руданському, Одеса 1968, с. 146.

${ }_{14}^{14}$ П. Й. Колесник, Творчість Степана Руданського, [в:] С. Руданський. Твори, у 3 томах, Київ 1971, т. 1, с. 27. 
Сучасні дослідники творчої спадщини С. Руданського, навпаки, схиляються до думки про те, що Байки світовї̈ є надзвичайно цікавим поетичним коментарем до вічних перлин християнства, своєрідним Євангелієм, що й досі не знайшло належного висвітлення. Однією з основних причин цього, очевидно, було бажання залишити поза увагою рядки поета, що яскраво підтверджують його глибоку віру в Сина Людського, свідомо обмежити образ Руданського. Із позицій сучасності Байки світовї не „дотепна пародія на деякі біблійні міфи, гострий памфлет з виразними атеїстичними тенденціями” 15 , а „картини й портрети особливого звучання та значення, бо маємо перший узагальнений погляд українського поета-класика на Старий та Новий Завіти, на Боже слово в фольклорній уяві і навіть його кредо як непохитного християнина" ${ }^{\prime \prime}$.

Справді, Байки світовї за авторською манерою викладу значно відрізняються від інших творів на релігійні теми. Як видається, у цьому разі також дається взнаки вплив бурлескно-травестійної традиції, започаткованої в українській літературі мандрівними дяками, у подальшому продовженої й поновому осмисленої Г. Сковородою, І. Котляревським і Т. Шевченком ${ }^{17}$. Ідеться про властиве травестії своєрідне „перелицьовування” добре відомого широкій аудиторії твору серйозного змісту й переробку його в жартівливому дусі, „переодяганні” його героїв. Величезний вплив на зміст Байок світових і, відповідно, на манеру їхнього викладу відіграли народні вірування, що на них і побудований твір С. Руданського, зокрема побутовий варіант розподілу небесної влади: влада неба й пекла різна; кого підтримує Бог, того боїться Сатана; хто тримається пекла, тому не перешкоджає Бог ${ }^{18}$.

Концепт „Бог” у Байках світових є одним із центральних, оскільки, як це й відображають народні уявлення, він $є$ основою й творцем усього сущого на землі. Його шанують селяни й міщани: „Аж тут - бам! В соборі дзвонять! —/Люди зворушились, / Шапки набожно підняли /I перехрестились" (с. 208); „І началась служба Божса. / Їдні люди входять, / помоляться і виходять, / Друziї надходять” (с. 210). Господу вірує й щиро молиться оповідач народних уявлень про сотворіння світу - старенький лірник, якого із симпатією детально описує С. Руданський: „, За дідами край притвори / Лірник прислонився, / Уклякнув і щииро-щциро / Господу молився. < .. > Лиш сліпий він, невидющий, / І очей не має; / А як сплили тії очі, / Лиш Бог їден знає” (с. 211). У фрагменті, що є вступом до поеми, названим С. Руданським Преслів 'ям, усвідомлюються такі смисли, характерні концепту „Бог”, як „повага людей”, „віра в нього”, „все знає”.

Значно повніше розкривається образ-концепт „Бог” у подальших розділах Байок світових, де його поет називає Бог великий, Бог сильний, Бог святий, Господь сильний, Господь милосердний, Господь небесний, Бог вічний, Бог правдивий, Бог праведний, Творець, Спаситель, вербалізуючи, відповідно, ядерні смисли „велич”, „сила”, „,вятість”, „милосердя”, „безсмертя”, „праведність”, „творець усього сущого”, „,паситель світу”.

Бог постає як творець усього сущого (, I задумав Бог $і$ наше / Небо освітити / I під небом нашу землю / Грішну сотворити”) (с. 214), чиї дії під час сотворіння життя є надзвичайними, містичними: ,, I зійшов Господь над море - / Море утихає” (с. 214); „I пішов Господь над море, / Ризу опускає - / I в годи-

15 Там само, с. 146.

${ }^{16}$ Степан Руданський (1834-1873). Поет, лікар, громадянин, Київ 2009, с. 103.

17 Г. М. Нога, Звичаї тії з давніх иколярів бували... (Украӥнський святковий бурлеск XVII - ХVIII століть), Київ 2001, с. 161-172.

18 Там само, с. 35. 
ні иіле море / В рибі закипає” (с.219); „І сказав Господь тій рибі / Землю підпирати” (с. 219); „I вернувся Бог до раю, / На престіл сідає, / I всіх ангелів до себе / 3 раю зазивае" (с. 219) та ін. Однак, незважаючи на святість, Бог у Байках світових виконує цілком конкретні діяння, притаманні звичайним селянам, що вербалізовані дієсловами на позначення побутових дій і фізіологічних станів: „, в взяв Господь тую землю, / Ходить, розсіває” (с. 216); „I спить Господь серед поля, / Сили відновляе" (с. 217); „I зійшов Бог з свого трону / I зачав місити. / Замісив - і чоловіка / 3 того став ліпити. / Виліпив, зачав стругати" (с. 221); „І рубає Ной з синами, / Бог їм помагає: / Що сокирою ударить — / Дерево спадає" (с. 241) та ін.

Персонажі Байок світових переважно виявляють шанобливе ставлення до Господа, що вербалізоване через їхні дії: Богу моляться („Пішла [Сва] собі за місточок, / Вийшла на дорогу / I ходила між садами / I молилась Богу" (c. 229); „I враз з батьком син заплакав, / помолився Богу” (с. 235); „Тілько Ной зачав безгрішний / Господа молити" (с. 238)); у нього просять допомоги (, І сказав він [Адам], іздихнувши: / „Поможси, мні, Божее!” (с. 232)); його прославляють: (I забули свої жалі [Адам і Сва], / I весело жили / працюювали, їли, пили, / Господа хвалили” (с. 234)).

Звертання до Бога як до вищої сили здійснюється в багатьох життєвих ситуаціях героїв: воно є й подякою, і проханням дати сили, і воланням про допомогу. До нього вдаються як люди, так і ангели (,„I все воїнство небесне / Богові служило(с. 220); I всі ангели злетілись, / Богу помолились / I святому його трону / Низько поклонились” (с. 220)).

Господь постає як такий, чиї дії є безапеляційними й не повинні викликати жодних сумнівів, негативних відчуттів, а лише подяку: „Ниньки родиться /на горе, / Взавтра умирає; / Ранком грає против сония, / Вечором згниває. / Но й за теє ми повинні / Господа хвалити, /Що й такими нам позволив / В білім свімі жсити" (с. 246).

Дії Бога не підлягають засудженню, бо вони є продуманими й досконалими: ,, Боже вічний, Боже дивний, / Праведний ти, Боже! / Хто тебе, правдивий Боже, / Осудити може? "(с. 250).

Актуалізовані вище приклади омовлюють смисли, що властиві досліджуваному концепту, серед яких такі, як „правильність”, „істина”, „досконалість”.

У радянському літературознавстві думку про те, що С. Руданський так вербалізує релігійні почуття українців, категорично відкидали, а фінальні рядки „Тілько Богу тра молитись, / Як годиться, жити / I святую волю Божу / Bid душі чинити!” (с. 305) коментували як „дивна” позиція „переконаного безбожника Руданського", яку він, передбачаючи цензурні ускладнення, висловив з метою надати темі „хоча б зовнішньо лояльного щодо церкви вигляду, сподіваючись у такий спосіб приспати пильність губителів вільного слова"19.

Можемо заперечити цю думку, адже поет укладає в уста лірника відвічне кредо справжнього християнина, у якому вербалізовані такі смисли, як „пошана до Бога”, „дотримання Божих заповідей” та ін.

Ті ж персонажі народних переказів про створення світу й, відповідно, Байок світових, що зневажливо ставляться до Бога, порушуючи його накази або глузуючи з них, зазнають кари. Так сталося із Сатанаїлом, який „над Богом кпився", бажаючи вбити Господа, втопивши його.

${ }^{19}$ Ю. І. Цеков, Зазнач. джерело, с. 117. 
Долі вигнанців із раю зазнали Адам і Сва, скуштувавши забороненого плоду. Страшний потоп поглинув тих, хто, незважаючи на заклики Ноя, „Рано Богу не молились / Посту не тримали / Їли, пили і гуляли, / Свят не шанували”" (с. 238). Відносно грішників, які порушують заповіді Господні, Всевишній є суворим: „І задумався Бог сильний, / Став думу гадати, / Яку кару грішним людям / За гріхи їх дати” (с. 239). Тут маємо омовлення смислів „суворість” і „покарання”.

Однак, попри свою суворість, Бог не залишає без допомоги навіть грішників, якщо вони того потребують і просять: „Болять крижі, болять руки, / Голова неможе, / I сказав він [Адам], іздихнувши: / „Поможи, мні, Боже!” / I поміг Господь небесний / Поле іскопати” (с. 232).

Стосовно ж праведників, які моляться Господу й дотримуються Законів Божих, Усевишній є добрим помічником, порадником і захисником: „Тешуть, колять, дошки пилять, / Бог їм помагає” (с. 242); „, I злітає ангел з неба / I говорить Ною: / „Не журися, вірний Ною: Сильний Бог з тобою! < .. > Помолися тілько Богу, / Щоби дав Бог сили” (с. 243); „I сказав Бог «Соломона / Щиро я кохаю / I своӥх літ йому дав би, / Та я літ не маю»" (с. 258) та ін. Отже, в поемі вербалізовано смисли „любов”, „милосердя”, „допомога”, ,захист”.

Одним із важливих засобів вербалізації образу-концепту „Бог” є, власне, мовлення самого Господа. Як у народних переказах і пізніше в поезії мандрівних дяків, Усевишній висловлюється за допомогою простих народних виразів. У Байках світових він, створюючи землю, навіть удається до народних заклинань: „Рости, рости, моя земле, / Куди глянуть очі: / Від восхода до полудня / I до полуночі!” (с. 216).

Як видається, у народній свідомості, а саме їі й передає С. Руданський, уживання народної лексики є одним із прийомів інтимізації оповіді, що має на меті передати близькість Творця до простої людини.

Засобом зближення, „олюднення” Бога є вживання ним просторічних слів і виразів. Цей прийом С. Руданський також міг запозичити в бурлескній поезії мандрівних дяків.

У деяких травестійних творах сварка Бога з Адамом більше схожа на суперечку персонажів 3 інтермедій. Бог хоч і лається, не добираючи слів, однак це характеризує його не лише як роздратованого й нещадного, a i як справедливого 20.

Подібне, хоча й не так категорично, без уживання лайливих виразів, але зі значною кількістю розмовних і діалектних слів, фразеологізмів, унаочнює, наприклад, розмова Бога 3 Адамом і Свою під час їхнього вигнання 3 раю: „, п промовив Бог до Сви, / Сви і Адама: „А ви, люди, не хотіли / В раю шануватись, / Тепер будете сльозами / Хліба дороблятись" (с. 231), де шануватися - розм. „Вести себе пристойно, як належить; слухатися” 21 , дороблятись - діал. „Працюючи, набувати, діставати що-небудь”22, або звертання Господа до Соломона: „, Соломоне-Соломоне! - / Стиха промовляє. — / Хоч крутися, не вертися, / Нічого діяти: / Видне діло, годі жити, / треба умирати. / Хоч крутися, не вертися, / Смерть перед тобою. / Ти якраз зійдешся з нею / Під горою тою" (с. 273), де вжиті варіанти ФО розмовного походження як не крути [як не верти] — „Що не роби, нічого не можна вдіяти”2з та звісне діло — „відомо, звичайно" 24 .

${ }^{20}$ Г. М. Нога, Зазнач. джерело, с. 144.

${ }^{21}$ Словник української мови, в 11 т., редкол.: акад. І. К. Білодід та ін., Київ 1978-1980, т. 11, c. 406.

${ }^{22}$ Там само, т. 2, с. 378.

${ }^{23}$ Словник фразеологізмів украӥнської мови, уклад. В. М. Біл он жжен ко та ін., Київ 2008, с. 316.

${ }^{24}$ Словник української мови ..., т. 3, с.488. 
Наближенню Бога до людей сприяє активне уживання ним української побутової лексики, напр.: „А Бог глянув на полицю. / «Що ж там на полиці?» / Вареники, либонь? - каже, — / Або варениці!” (с. 294). Це можемо розцінювати як травестійний елемент, активно використовуваний і мандрівними дяками, і І. Котляревським ${ }^{25}$.

У поемі Байки світовії виразно вербалізовано як Бога-Отця, так і БогаСина, що відображає розділ „Бог на землі”. У творі немає жодного натяку на іронічну чи жартівливу конотацію в сприйнятті Сина Божого, оскільки в культурі нашого народу його вважають покровителем та благом для всіх українців. Згідно з українською релігійною традицією Ісус Христос постає як Спаситель світу, адже до його народження на землі діялися всілякі неподобства (, ,Гірко було в світі жити, / Гірко і родитись. / Все в нім було зіпсувалось, / Попереверталось, / I будівля світовеє / Мало щзо трималось” (с. 275)), а його поява зумовлена Божою волею врятувати грішний світ.

С. Руданський використовує прийом інтертекстуалізаиії, переплітаючи в тканині тексту біблійні історії про народження Сина Божого Дівою Марією (звістка про зачаття Ісуса Христа, повідомлена Марії ангелом, народження Ісуса Христа в яслах по дорозі до Віфлиєма, прихід до ясел пастухів, побиття немовлят Іродом, перетворення води на вино і под.) з народними переказами (про коня, який розривав сіно над новонародженим Ісусом, вола, який обігрівав Його своїм диханням, каню, яка не хотіла допомагати Ісусу разом із іншими тваринами будувати греблю, щоб зупинити потоп).

Письменник органічно вводить у загальний розвиток сюжету народну колядку Видить Бог, видить Отець, що, як видається, також сприяє інтимізації оповіді, наближенню образа Ісуса Христа до читачів, наприклад: „А тим часом радість стала, / Яка не бувала, / Над вертепом зоря ясна / Світом засіяла < .. > Що в вертепі Бог родився, / 3 діви воплотився, / Як дитина, пеленами / Бідно уповився" (с. 278).

Очевидно, у народних переказах, на яких заснований твір С. Руданського, немає чіткого розмежування між Творцем і його Сином, тому образ-концепт Ісуса Христа набуває таких смислів, як „сотворіння тварин”, „покарання грішників за непослух”, що традиційно характерні для Бога-Отця, порівн.: „, Аж nidходить тут і Господь / I почав казати: / „Хто розсипав ті гадюки, / Мусить позбирати”. I крилами стали руки, / Рогом ніс облився / I з иікавого сіроми / Бусель ізробився” (с. 285); „I скарав його Син Божий / Карою своєю: / Плуг, плугатар і погонич / Щезли під землею” (с. 291).

Разом із тим, в образі Ісуса Христа актуалізуються такі ядерні смисли: „напучування, навчання християнських істин”, „проповідництво”, „сотворіння дива”, „жертовність”, „воскресіння Ісуса як порятунок світу”, причому, згідно 3 українською христоцентричною культурною традицією, він позбавлений жартівливої конотації, порівн.: „, прийшов Господь до изеркви, / Став народ скликати / I у цееркві на амвоні / Людям став казати: "Я, Ісус Христос, син Божсий, / Кажу, щуоб ви знали, / Щоб ви день недільний чтили, / Свята шанували. / <...> Бути свідками неправди / Тяжко стережіться, / Людям кривди не робіте, / Дармо не кленіться!»” (с. 291-293); „I казав Господь принести / Води із криниці, < ...> I принесли, виливають, / Аж тут диво сталось: / Зо всіх відер, скілько було, / Вино виливалось!'”(с. 295); ,Все те правда, - Господь кажсе, / Все те живо буде: / Все те маю я терпіти / За мир $і$ за люди!” (с. 301);

\footnotetext{
${ }^{25}$ Г. М. Нога, Зазнач. джерело, с. 153.
} 
„I Господь наш і Спаситель / 3 гробу воскресає. <.. > I вознісся Бог на небо, А ми тут жиємо, / Та колись і ми на небі / 3 Господом будемо” (с. 305).

У радянському літературознавстві Байки світовї розглядали переважно як твір, що є гумористичним відображенням народних релігійних уявлень, який має „...деякі спільні риси 3 антицерковними сатиричними гуморесками Руданського"26. Однак укотре наполягаємо на думці щодо зумисного відображення поетом народних легенд на релігійну тему 3 елементами бурлескнотравестійної традиції, що аж ніяк не є ознакою антирелігійності, а є спрощеною альтернативою офіційній релігійній літературі. Г. Нога пише, що „серйозна духовна література, покликана підтримувати стосунки між людиною і Богом на певному рівні, шлях до серця мирянина прокладається саме через психологію, глибинні шари свідомості. Бурлескна література не занурюється так глибоко. Її вплив на людину обмежується поверхневими контактами. Вона породжує сміх, розважає, руйнує лише зовнішні схеми, залишаючи недоторканими внутрішні, глибоко закорінені переконання і уявлення людини, тобто сприймання мирянином одночасно двох літературних типів християнської ідеї не є суперечливим"27.

Отже, той факт, що Байки світовї не були видані за життя С. Руданського, навряд чи пояснюється „виразним антирелігійним спрямуванням поеми”28. Швидше, це свідчення чергового бойкоту імперською російською цензурою всього українського, самобутнього, яким, безперечно, і є поема Байки світовіi. У поемі Байки світовї образ-концепт „Бог” омовлено абсолютно позитивно, що демонструє вживання як позитивно конотованих іменувань Господа (Бог великий, Бог сильний, Бог святий, Господь сильний, Господь милосердний, Господь небесний, Бог вічний, Бог правдивий, Бог праведний, Твореиь, Спаситель та ін.), так і постійна актуалізація ядерних смислів (,велич”, „сила”, „святість”, „милосердя”, „безсмертя”, „праведність”, „творець усього сущого”, „спаситель світу” та ін.). Виявляючи суворість, він одночасно є й близьким до людей. Відсутність жартівливої конотації в зображенні образу Ісуса Христа засвідчує христоцентричність української культури, у якій Син Божий посідає особливе місце.

\footnotetext{
${ }^{26}$ I. І І. Пільгук, Степан Руданський. Нарис життя і творчості, Київ 1956, с. 88.

27 Г. М. Нога, Зазнач. джерело, с. 157.

${ }^{28}$ П. Гопченко, Зазнач. джерело, с. 147.
} 